\title{
Interpersonal Communication Analysis of Students at Schools That Use Social Media In The New Normal Era
}

\author{
Riean Rachma Yuniar \\ Jurusan Bimbingan dan Konseling Pendidikan Islam, \\ Fakultas Tarbiyah dan Ilmu Keguruan, IAIN Kerinci \\ e-mail: riean.rachma@yahoo.com

\section{Dosi Juliawati} \\ Jurusan Bimbingan dan Konseling Pendidikan Islam, \\ Fakultas Tarbiyah dan Ilmu Keguruan, IAIN Kerinci. \\ e-mail: dosi@konselor.org
}

\author{
Ahmad Jamin \\ Jurusan Pendidikan Agama Islam, Fakultas Tarbiyah \\ dan Ilmu Keguruan, IAIN Kerinci. \\ e-mail: ahmadjamin81@gmail.com

\section{Hengki Yandri} \\ Jurusan Bimbingan dan Konseling Pendidikan Islam, \\ Fakultas Tarbiyah dan Ilmu Keguruan, IAIN Kerinci. \\ e-mail: hengki@konselor.org
}

\begin{abstract}
Abstrak
Komunikasi antarpribadi merupakan salah satu modal utama seseorang untuk sukses dalam menjalani kehidupan sehari-hari termasuk di sekolah. Kemampuan komunikasi antarpribadi yang baik akan menunjang keberhasilan siswa di sekolah, namun tidak semua siswa memiliki kemampuan komunikasi antarpribadi terutama siswa yang aktif menggunakan media sosial. Sehingga, tujuan penelitian ini untuk mengungkap komunikasi antarpribadi siswa yang menggunakan media sosial. Penelitian dilakukan dengan desain eksperimental menggunakan metode kuantitatif deskriptif dengan jumlah responden 31 orang siswa kelas VIII Sekolah Menengah Pertama Negeri 24 Kerinci yang diambil menggunakan teknik purposive sampling. Data diungkap menggunakan skala komunikasi antar pribadi dan data yang sudah dikumpulkan kemudian dianalisis dengan rumus persentase, selanjutnya dilakukan penafsiran skor perolehan hasil penelitian dengan menggunakan skor ideal. Hasil penelitian mengungkapkan bahwa rata-rata siswa yang menggunakan media sosial di sekolah memiliki komunikasi antarpribadi yang tidak baik. Hasil penelitian lebih lanjut akan disampaikan dalam artikel ini.
\end{abstract}

Kata Kunci: komunikasi antarpribadi, media sosial, era new normal

\begin{abstract}
Interpersonal communication is one of the main asset of a person to succeed in daily life including in the school. Good interpersonal communication skills will support students' success in the school, but not all students have interpersonal communication skills, especially those who are active in social media. Thus, the aim of this research is to reveal the interpersonal communication of students who use social media. This research used a descriptive quantitative method with the number of respondents were 31 students of seventh grade at State Junior High School of 24 Kerinci which was taken by using the purposive sampling technique. Data were revealed by using the scale of inter-private communication and then, the data collected were analyzed by using the percentage formula. Afterwards, the interpretation of the acquisition score of research results done by using the ideal score. The results reveal that in general, the students who use social media in the school have poor interpersonal communication.
\end{abstract}

Keywords: interpersonal communication, social media, new normal era

\section{PENDAHULUAN}

Perkembangan ilmu pengetahuan dan teknologi masa kini mengharuskan manusia memiliki kemampuan menyesuaikan diri dengan baik terhadap upaya-upaya pembaharuan dan pemanfaatan teknologi yang memiliki dampak pada penggunaan multimedia dalam penyebaran informasi dan komunikasi melalui jaringan internet (Arsyad, 2002). Berdasarkan riset Kominfo yang disampaikan oleh Ahmad M. Ramli pada webinar yang dilaksanakan tanggal 9/30 2020 menunjukan bahwa pengguna internet pada 2020 itu sebanyak 175,5 juta mengalami kenaikan 25 juta atau 17 persen dibandingkan tahun sebelumnya pada 2019.

Pemanfaatan internet saat ini bisa dilakukan oleh siapa pun, kapan pun dan dimanapun contohnya pada saat ini hampir semua alat komunikasi seperti handphone memiliki aplikasi yang memudahkan penggunanya untuk 
menjelajah internet. Aplikasi handphone masa kini sudah memiliki berbagai macam fitur alat komunikasi yang sering disebut dengan media sosial. Media sosial adalah media Online yang penggunanya sangat mudah untuk berpartisipasi, menciptakan isi meliputi blog, forum, jejaring sosial, Wiki, Facebook, WhatsApp, Telegram, Youtube, Line, Twitter, dan Instagram (Putri et al, 2016). Riset juga menunjukkan bahwa penggunaan media sosial dan digital menjadi bagian yang menyatu dalam kehidupan sehari-hari anak muda Indonesia. Studi ini menemukan bahwa 98 persen dari anak-anak dan remaja yang disurvei tahu tentang internet dan bahwa 79,5 persen diantaranya adalah pengguna internet (Kominfo RI, 2014).

Internet mempunyai banyak pengaruh atau dampak terhadap perubahan kehidupan manusia dari segala bidang, seperti hubungan sosial, berkurangnya rasa empati dan kepedulian terhadap sesama. Perkembangan yang negatif akan terlihat dalam berbagai sikap dan tingkah laku yang menyimpang (Drajat, 2007). Remaja yang berada pada fase pencarian identitas diri akan mudah mengalami kesulitan dalam mengontrol tingkah lakunya (Afrifadela et al, 2020) dan mereka sangat mudah terpengaruh dengan informasi dari luar jika tidak disaring dengan baik oleh mereka. Remaja sangat mudah melakukan konformitas bersama dengan teman sebayanya (Sartika \& Yandri, 2019) jika tidak dibimbing oleh orang dewasa seperti orang tua dan guru di sekolah. Kemampuan komunikasi siswa akan menjadi terhambat karena jarangnya mereka mendapatkan contoh dan model yang tepat dalam melakukan komunikasi. Padahal komunikasi merupakan alat penyampai pesan yang bisa merubah tingkah laku seseorang (Rubent \& Stewart, 2006) dan hal ini mesti wajib dimiliki siswa di sekolah untuk mengembangkan kecakapan hidupnya.

Komunikasi antarpribadi bersifat dialogis, dalam arti arus balik antara komunikator dengan komunikan terjadi langsung, sehingga pada saat itu juga komunikator dapat mengetahui secara langsung tanggapan dari komunikan, dan secara pasti akan mengetahui apakah komunikasinya positif, negatif dan berhasil atau tidak. Apabila tidak berhasil, maka komunikator dapat memberi kesempatan kepada komunikan untuk bertanya seluas-luasnya. Sebagaimana yang telah dikemukakan dalam penegasan istilah, penelitian ini lebih ditekankan pada dimensi psikologis perilaku komunikasi antarpribadi siswa. Sehingga secara psikologis perilaku komunikasi antarpribadi siswa meliputi keterbukaan, empati, dukungan, rasa positif dan kesetaraan (Novianti et al, 2017). Komunikasi antar pribadi ini akan lebih efektif jika dilakukan langsung dengan tatap muka dengan lawan bicara, namun dalam kondisi pandemi COVID-19, hal ini akan sangat sulit dilakukan karena harus menjaga jarak dengan orang lain.

Pada masa pandemi COVID-19 ini, pemerintah Indonesia mengeluarkan istilah New Normal yang berarti melakukan penyesuaian perilaku untuk tetap menjalankan aktivitas normal, tapi ditambah dengan penerapan protokol kesehatan guna mencegah terjadinya penularan COVID-19 (Fajar, 2020). Dengan demikian, setiap aktivitas yang dilakukan di luar rumah harus mengikuti protokol kesehatan termasuk kegiatan belajar di sekolah. Hal ini semakin mempersempit ruang gerak siswa dalam melakukan komunikasi jarak dekat dengan orang lain, padahal komunikasi merupakan keterampilan yang harus diasah sehingga makin mahir. Sama halnya seperti keterampilan komunikasi antarpribadi di masa pandemi COVID-19 ini juga harus diasah oleh siswa di sekolah, karena waktu siswa belajar lebih banyak dihabiskan dalam jaringan (daring) dari rumah ketimbang berinteraksi langsung dengan guru atau teman di sekolah. Penelitian terhadap pola komunikasi anak dan remaja melalui internet mengungkapkan komunikasi yang dilakukan dengan teman sebaya, guru, dan anggota keluarga dilakukan dengan cukup signifikan (Kominfo RI, 2014) ketimbang berbicara langsung dengan teman sebaya, guru, dan dengan orang tua mereka.

Dari hasil studi awal penulis kepada orang tua siswa mengungkapkan bahwa mereka merasakan intensitas komunikasi dengan anak-anak mereka semakin sedikit, karena anak-anak mereka lebih banyak bermain dengan handphone mereka ketimbang berinteraksi dengan orang tua mereka. Kemudian siswa lebih banyak menghabiskan waktunya bermain handphone untuk melihat media sosial di waktu jam istirahat sekolah ketimbang berkomunikasi dengan temannya secara langsung, selanjutnya keterangan dari guru mata pelajaran mengungkapkan bahwa kegiatan belajar di masa pandemi COVID-19 ini banyak dilakukan secara daring sehingga intensitas komunikasi dengan siswa semakin jauh berkurang. Hal ini disinyalir mengakibatkan kemampuan komunikasi antar pribadi siswa semakin buruk

Dari kajian literatur dan paparan data sebelumnya, penulis menyimpulkan bahwa keterampilan komunikasi antarpribadi harus dimiliki siswa agar mereka memiliki keterampilan hidup secara sosial di masyarakat, dan penggunaan media sosial harus dimanfaatkan oleh siswa dengan cara yang lebih bijak. Sehingga tujuan dari penelitian ini yaitu untuk mengungkap pola komunikasi antarpribadi siswa di sekolah yang menggunakan media sosial di era New normal.

\section{METODE}


Penelitian ini dilaksanakan dengan desain eksperimen menggunakan metodologi kuantitatif deskriptif yang bertujuan untuk mendeskripsikan data, fakta-fakta dan sifat-sifat dari responden penelitian secara sistematis, faktual dan akurat secara detail (Yusuf, 2013; Sugiyono, 2016). Tujuan penelitian ini yaitu untuk mendeskripsikan komunikasi antarpribadi siswa di sekolah yang menggunakan media sosial secara faktual dan akurat. Populasi penelitian ini yaitu seluruh siswa kelas VIII Sekolah Menengah Pertama Negeri 24 Kerinci yang berjumlah 31 orang. Dalam menentukan sampel penelitian, peneliti menggunakan teknik purposive sampling dengan kriteria responden yang menjadi sampel yaitu sebagai berikut: (a) terdaftar sebagai siswa aktif di SMPN 24 Kerinci; (b) siswa kelas VIII; (c) siswa kelas VIII memiliki media sosial (Facebook, tweeter, Instagram, whatsapp); (d) siswa kelas VIII yang bersedia menjadi responden penelitian.

Pengumpulan data dalam penelitian ini dilakukan menggunakan skala komunikasi antar pribadi yang peneliti susun sendiri dan sudah divalidasi oleh ahli dibidangnya dan telah diuji reliabilitas dengan nilai Alpha Cronbach's 0,821. Data yang sudah dikumpulkan kemudian dianalisis dengan rumus persentase, selanjutnya dilakukan penafsiran skor perolehan hasil penelitian guna mendeskripsikan tingkatan skor komunikasi antarpribadi siswa yang menggunakan media sosial. Tingkatan skor perolehan responden ini dihitung dengan rumus skor ideal (Azwar, 2010; Juliawati \& Yandri, 2018).

\section{HASIL DAN PEMBAHASAN}

Berdasarkan pengolahan data hasil penelitian yang telah dilakukan, maka bisa dijabarkan temuan penelitian tentang komunikasi antarpribadi siswa yang menggunakan media sosial berdasarkan aspek komunikasi antarpribadi sebagai berikut:

Tabel 1.Distribusi Frekuensi Aspek Komunikasi Antarpribadi Siswa yang Menggunakan Media Sosial.

\begin{tabular}{llcc}
\hline \multicolumn{1}{c}{ Aspek } & Kategori & Frekuensi & Persentase \\
\hline \multirow{2}{*}{ Keterbukaan } & Baik & 14 & 45.16 \\
& Buruk & 17 & 54.84 \\
Empati & Baik & 12 & 38.71 \\
& Buruk & 19 & 61.29 \\
Mendukung & Baik & 13 & 41.94 \\
Lawan Bicara & Buruk & 18 & 58.06 \\
& Baik & 13 & 41.94 \\
Kesetaraan & Buruk & 18 & 58.06 \\
& Baik & 14 & 45.16 \\
Sikap Positif & Buruk & 17 & 54.84 \\
\hline
\end{tabular}

Data pada tabel 1 menunjukkan bahwa responden yang mempunyai akun media sosial cenderung memiliki komunikasi antarpribadi yang buruk. Berdasarkan aspek keterbukaan contohnya, dari 31 orang responden penelitian ada sebanyak 14 orang yang bisa melakukan komunikasi antar pribadi dengan baik atau sebesar $45,16 \%$ dan 17 orang responden belum memiliki keterampilan komunikasi antar pribadi yang baik yaitu sebanyak 54,84\%. Kemudian dari aspek empati siswa mengungkapkan bahwa ada 12 orang responden sudah memiliki keterampilan komunikasi antar pribadi yang baik atau sebesar 38,71\% dan 19 orang responden belum memiliki keterampilan komunikasi antarpribadi yang baik yaitu sebesar $61,29 \%$.

Seterusnya, pada aspek mendukung lawan bicara, dari 31 orang responden ada 13 orang sudah memiliki keterampilan komunikasi antarpribadi yang baik atau sebesar $41,93 \%$ dan sebanyak 18 orang responden belum memiliki keterampilan komunikasi antarpribadi yang baik yaitu sebesar 58,06\%. Lebih lanjut, dari aspek kesetaraan, mengungkapkan bahwa dari 31 orang responden ada sebanyak 13 orang responden yang sudah memiliki keterampilan komunikasi antarpribadi yang baik atau sebesar41,94\% dan 18 orang responden belum memiliki keterampilan komunikasi yang baik yaitu sebesar 58,06\%. Terakhir pada aspek sikap positif, dari 31 orang responden ada sebanyak 14 orang responden sudah menampilkan sikap positif ketika melakukan komunikasi antarpribadi atau sebanyak $45,16 \%$ dan ada 17 orang responden belum menunjukkan sikap positif saat melakukan komunikasi antarpribadi yaitu sebesar $54,84 \%$.

Kemudian, jika dianalisis komunikasi antarpribadi siswa yang menggunakan media sosial berdasarkan jenis kelamin, maka bisa dilihat pada tabel 2 berikut ini:

Tabel 2. Distribusi Frekuensi Komunikasi Antarpribadi Siswa yang Menggunakan Media Sosial berdasarkan Jenis Kelamin

\begin{tabular}{llcc}
\hline Jenis Kelamin & Kategori & Frekuensi & Persentase \\
\hline \multirow{2}{*}{ Laki-laki } & Baik & 5 & 38.46 \\
& Buruk & 8 & 61.54 \\
\multirow{2}{*}{ Perempuan } & Baik & 8 & 44.44 \\
& Buruk & 10 & 55.56 \\
\hline
\end{tabular}

Dari tabel 2 ini terlihat bahwa, baik siswa laki-laki maupun siswi perempuan pada umumnya sama-sama belum memiliki keterampilan komunikasi antar pribadi yang baik di sekolah. Data komunikasi antarpribadi siswa laki-laki dari 13 orang responden menunjukkan ada 5 orang responden sudah memiliki komunikasi antarpribadi yang baik atau sebesar 38,46\% dan sebanyak 8 orang responden belum memiliki komunikasi antarpribadi yang 
baik yaitu sebesar $61,54 \%$. Kemudian dari 18 orang siswi perempuan menunjukkan ada 8 orang responden sudah memiliki keterampilan komunikasi antar pribadi yang baik atau sebesar 44,44\% dan 10 orang responden belum memiliki komunikasi antar pribadi yang baik yaitu sebesar $55,56 \%$.

Kemudian untuk melihat data secara keseluruhan hasil dari analisis komunikasi antarpribadi siswa yang menggunakan media sosial di era New normal bisa dilihat pada tabel 3 berikut.

Tabel 3. Distribusi Frekuensi Komunikasi Antarpribadi Siswa yang Menggunakan Media Sosial

\begin{tabular}{clcc}
\hline \multicolumn{1}{c}{ Variabel } & Kategori & Frekuensi & Persentase \\
\hline Komunikasi & Baik & 13 & 41.94 \\
Antarpribadi & Buruk & 18 & 58.06 \\
\multicolumn{2}{c}{ Jumlah } & $\mathbf{3 1}$ & $\mathbf{1 0 0}$ \\
\hline
\end{tabular}

Secara keseluruhan terlihat dari tabel 3 di atas bahwa rata-rata siswa belum memiliki keterampilan komunikasi antarpribadi yang baik. Dari 31 orang responden ada 13 orang yang sudah memiliki keterampilan komunikasi antarpribadi yang baik atau sebesar 41,94\% dan 18 orang responden belum memiliki komunikasi antarpribadi yang baik yaitu sebesar 58,06\%. Hasil penelitian ini memberikan gambaran bahwa perlunya perhatian khusus bagi pihak sekolah terutama guru BK di sekolah agar memberikan layanan yang sesuai dengan kebutuhan siswa agar siswa mampu memanfaatkan media sosial dengan baik dan efisien.

Temuan penelitian ini juga sejalan dengan temuan penelitian terdahulu yang mengungkapkan bahwa secara statistik terdapat pengaruh kecemasan sosial terhadap ketergantungan pada media sosial yang signifikan (Soliha, 2015). Hal ini berarti, seseorang dengan tingkat kecemasan sosial yang tinggi akan mendorong mereka untuk memanfaatkan media sosial dan akan melibatkan diri dalam melakukan komunikasi Online secara mendalam. Individu yang cerdas secara emosi biasanya akan mampu mengontrol dirinya dalam bersikap dan bertindak termasuk halnya dalam melakukan komunikasi (Juliawati \& Yandri, 2018; Ulandari \& Juliawati, 2019; Faiz et al, 2019).

Kemudian hasil penelitian terdahulu juga menunjukkan bahwa kepercayaan diri seseorang memiliki pengaruh yang signifikan dengan kemampuan komunikasi antarpribadi seseorang (Utami et al, 2015). Hal ini berarti, kemampuan siswa dalam melakukan komunikasi antar pribadi di pengaruhi juga oleh kepercayaan diri yang dimiliki oleh siswa itu sendiri, semakin rendah kepercayaan diri yang dimilikinya maka kemampuan komunikasi siswa akan semakin buruk.

\section{PENUTUP}

\section{Simpulan}

Berdasarkan data temuan hasil penelitian ini, maka ditarik kesimpulan yaitu rata-rata siswa yang memasuki era New normal dalam menggunakan media sosial di sekolah memiliki komunikasi antarpribadi yang buruk. Kemudian berdasarkan jenis kelamin, baik siswa laki-laki maupun siswi perempuan pada umumnya sama-sama belum memiliki keterampilan komunikasi antar pribadi yang baik di sekolah. Kemudian, kemampuan guru dalam memanfaatkan komunikasi antarpribadi juga akan membantu siswa mudah dalam mengaplikasikan keterampilan komunikasi antar pribadi disekolah (Rahardja, 2004). Artinya, guru harus bisa memberikan teladan yang baik dalam menerapkan komunikasi antarpribadi di sekolah sehingga siswa bisa mencontoh model komunikasi dari gurunya.

\section{Saran}

Dari hasil penelitian ini, disarankan kepada guru BK di sekolah untuk memberikan layanan bimbingan dan konseling yang inovatif yang bisa mengakomodasi siswa agar memiliki keterampilan dalam memanfaatkan media sosial dengan bijak, sehingga memiliki pengaruh positif terhadap komunikasi antarpribadi siswa di sekolah. Kemudian kepada peneliti selanjutnya, untuk dapat meneliti dengan responden yang lebih luas dan merancang program BK yang tepat untuk masalah komunikasi antarpribadi siswa.

\section{DAFTAR PUSTAKA}

Arsyad, A (2002). Media Pembelajaran, Jakarta: Raja Grafindo Persada.

Azwar, S. (2010). Penyusunan Skala Psikologi. Yogyakarta: Pustaka Pelajar.

Drajat, Z. (2007). Psikologi Agama. Jakarta: Raja Grafindo Persada.

Faiz, A., Yandri, H., Kadafi, A., Mulyani, R. R., Nofrita, N., \& Juliawati, D. (2019). Pendekatan Tazkiyatun An-Nafs untuk Membantu Mengurangi Emosi Negatif Klien. Counsellia: Jurnal Bimbingan dan Konseling, 9(1), 65-78. https://doi.org/10.25273/counsellia.v9i1.4300 .

Fajar. (2020, May 31). Pandemi COVID-19: Mengenal Konsep New Normal. Retrieved from INDONESIA.GO.ID:https://indonesia.go.id/ragam/ko moditas/ekonomi/mengenal-konsep-new-normal.

Juliawati, D., \& Yandri, H. (2018). Prokrastinasi Akademik Mahasantri Ma'had Al Jami'ah IAIN Kerinci. Jurnal Fokus Konseling, 4(1), 19-26. 
Juliawati, D., Yandri, H., \& Afrifadela, N., (2020). Self Contorl Belajar Siswa di Sekolah dalam Menghadapi Era Revolusi Industri 4.0. Tarbawi: Jurnal Ilmu Pendidikan. 16(2), 77-86. https://doi.org/10.32939/tarbawi.v16i01.557

Kominfo RI. (2014, Februari 18). Riset Kominfo dan UNICEF Mengenai Perilaku Anak dan Remaja dalam Menggunakan Internet. Retrieved from Kementerian Komunikasi dan Informatika Republik Indonesia: https://kominfo.go.id/

Nopiarni, R., Yandri, H., \& Juliawati, D. (2020). Perilaku Membolos Siswa Sekolah Menengah Atas di Era Revolusi Industri 4.0. Bikotetik (Bimbingan dan Konseling: Teori dan Praktik), 4(1), 21-24. http://dx.doi.org/10.26740/bikotetik.v4n1.p21-24

Novianti, R. D., Sondakh, M., \& Rembang, M. (2017). Komunikasi Antarpribadi dalam Menciptakan Harmonisasi (Suami dan Istri) Keluarga di Desa Sagea Kabupaten Halmahera Tengah. e-journal "Acta Diurna", 6 (2): 5-6

Putri, W. S. R., Nurwati, N., \& Budiarti, M. (2016). Pengaruh media sosial terhadap perilaku remaja. Prosiding Penelitian dan Pengabdian kepada Masyarakat, 3(1).

Rahardja, A. T. (2004). Hubungan Antara Komunikasi antar Pribadi Guru dan Motivasi Kerja Guru dengan Kinerja Guru SMUK BPK PENABUR Jakarta. Jurnal Pendidikan Penabur, 3(3).

Rubent, B. D., \& Stewart, L.P. (2006). Komunikasi dan Perilaku Manusia, Jakarta: Rajawali Press.

Sartika, M., \& Yandri, H. (2019). Pengaruh Layanan Bimbingan Kelompok Terhadap Konformitas Teman Sebaya. Indonesian Journal of Counseling and Development, $1(1), \quad 9-17$. https://doi.org/10.32939/ijcd.v1i1.351

Soliha, S. F. (2015). Tingkat Ketergantungan Pengguna Media Sosial dan Kecemasan Sosial. Jurnal Interaksi. 4 (1).

Sugiyono. (2016). Metode Penelitian Kuantitatif, Kualitatif dan $R \& D$. Bandung: Alfabeta.

Ulandari, Y., \& Juliawati, D. (2019). Pemanfaatan Layanan Bimbingan Kelompok Untuk Meningkatkan Kecerdasan Emosi Siswa. Indonesian Journal of Counseling and Development, 1(1), 1-8. https://doi.org/10.32939/ijcd.v1i1.350

Utami, D., Yusmansyah, Y., \& Utaminingsih, D. (2015). Hubungan Antara Percaya Diri dengan Kemampuan Komunikasi Interpersonal pada Siswa SMA. ALIBKIN (Jurnal Bimbingan Konseling), 4(2).

Yusuf, A. M. (2013). Motede Penelitian Kuantitatif, Kualitatif dan Penelitian Gabungan. Padang: UNP Press 